\title{
The Fate of Glyphosate in Soil and Water: A Review
}

\author{
Suwardji ${ }^{*}$, I Made Sudantha² \\ ${ }^{1}$ Department of Soil Science Faculty of Agriculture, University of Mataram, Jalan Pendidikan No 37 Mataram Lombok, Indonesia. \\ ${ }^{2}$ Department of Agronomy Faculty of Agriculture, University of Mataram, Jalan Pendidikan No 37 Mataram Lombok, Indonesia.
}

DOI: 10.29303 /ippipa.v7iSpecialIssue. 971

\section{Article Info}

Received: September 19th, 2021

Revised: December 20th 2021

Accepted: December 31st, 2021

\begin{abstract}
The fate of glyphosate in soil and water is dependent on the properties of glyphosate and its envoronement. Behaviour of glyphosate in soil, sediment and water is strongly influenced the way by which it can be adsorbed by soils, sediments, and suspended material in water. The role of soil organic matter, clay mineral, and amorphous minerals on the adsorption of glyphosate depends primarily on the nature and properties of the soil itself and the properties of glyphosate. Environmental factors have some influence on sorption and degradation of glyphosate. Glyphosate is rapidly inactivated in soil, is in part due to adsorption. Some soil properties have been identified strongly influence adsorption of glyphosate, such as clay minerals, composition of cations in exchangeable site of clay and organic matter, unoccupied phosphate adsorption site, degree of humification, and soil $\mathrm{pH}$. Adsorption limits the availability of glyposate for microbial degradation. The sorbed glyphosate is not directly available to microorganisms in soil. Evidence also suggests that not only a strongly sorbed compound such as paraquat but also weakly sorbed compounds such as flumetsulam and picloram can persist for long periods when they are sorbed by soil constituents. This suggests that the interaction between sorption and biodegradation should be considered in predicting the fate of pesticides in soils and sediments.
\end{abstract}

Keywords: The Fate of glyphosate; Glyphosate properties; Adsorption and degradation behaviour of glyphosate; Sorbed and soluble

Citation: Suwardji, S., \& Sudantha, I M. (2021). The Fate of Glyphosate in Soil and Water: A Review. Jurnal Penelitian Pendidikan IPA, 7(SpecialIssue), 389-399. https:// doi.org/10.29303/jppipa.v7iSpeciallssue.971

\section{Introduction}

In order to be able to effectively control the environmental risk resulting from the application of pesticides, it is important to understand how pesticides behave in soils and water. Soil is the ultimate sink for many pesticides used, while at the same time, soil may become a source from which pesticide residues can move into living organisms, ground and surface waters and the atmosphere (Gerstl and Mingelgrin 1984; Rao and Hornsby, 2001).

Pesticides can reach soils either by direct application or indirectly, for example, from inaccurate spraying technique, runoff, rain and dust. Some pesticides can also be absorbed by plant through the leaves and may remain unchanged and become part of soil organic matter with the death of leaves and subsequent decay of the plant (Burns 1975; Rampazzo, 2009).

When pesticides reach the soils, they may undergo one or more of several processes. These include evaporation, photochemical degradation, leaching, runoff, plant removal, adsorption, chemical and microbial degradation (Rampazzo, 2009; Kanissery, et al, 2019; Sarkar, et al, 2020). Adsorption and degradation are two of the most important processes influencing the residue behaviour of most pesticides in soils and sediments (Cox, et al. 1993; Hermosin \& Carnejo 1990; Rao and Hornsby 2001). These processes are not only control the mobility and potential for

\footnotetext{
*Email: suwardji@unram.ac.id
} 
leaching of the pesticide away from the site of application but also strongly influence the uptake of pesticide by plant root and soil fauna (Gerstl \& Mingelgrin, 1984; Simonsen, et al, 2008)

Adsorption and degradation of pesticides and other organic compounds in soils and sediments have been extensively reviewed in the literature (Calvet, 1980; Hance, 1988; Hassett\&Banwart 1989; Koskinen\& Harper 1990; Bollag \& Liu, 1990; Cork \& Krueger, 1991; Arunakumara et al. 2013; Sviridov, et al, 2015; SadeghZadeh, et al, 2017; Kanissery, et al, 2019). This review will discuss the basic concept of adsorption in relation to the sorptive properties of soil, will consider factors which influence adsorption and degradation of pesticides in soils, how sorption influences degradation of pesticides, kinetics of biodegradation of sorbed chemicals, and the behaviour and metabolism of glyphosate in soil and sediments.

Glyphosate is pre-emergence herbicide and widely used in agriculture to control wide range of weeds (Kremer and Means, 2019). Considerable information is available on the chemistry of glyphosate, its mode of action, and the effect of this compound on the plant metabolism (Piccolo \& Celano, 1994; Mallik, et al. 1989; Sadegh-Zadeh, et al, 2017). However, very little information is available on the ehavior of this compound in a wide range of soils (Torstensson, 1985; Ronaldo, et al, 2017)). The rate of decomposition of this compound in soil has been shown to be strongly dependent on the sorption characteristic of soil (Eberbach 1998; Wang, et al, 2016; Zhang, et al, 2015), yet a simultaneous process of sorption-desorption, and the influence sorption on the rate of decomposition in soils is not well understood. Moreover, little is known regarding the influence of environmental factors particularly temperature on the sorption and decomposition of this compound.

A major gap in our understanding of the fate of pesticide in soil and water is inability to predict the influence of sorption on biodegradation. This is due to a lack of a method, which is capable of quantifying the various strengths of adsorption that exist where multiple sorption mechanisms exist. A method should look at how strength of adsorption influences the rate of herbicide degradation "in situ". The use of a Non Steady State Compartmental Analysis (NSSCA) (Winkler, 1971) using glyphosate degradation data has been shown to discriminate between the soluble and sorbed glyphosate "in situ" (Eberbach, 1998). This technique shows its applicability for explaining the dependence of herbicide degradation on strength of adsorption, but as yet has not been used extensively in herbicide research (Suwardji, 1998).
This review paper is a part of three consecutive reseach papers will be published in this Journal of Research in Science Education.

\section{Method}

Some scientific publications used in this review are from books and articles from scientific papers published in international journals related to the sorption behavior of glyphosate in soil and water and its relationship to the process of glyshoste decomposition behavior. Data from various sources of information are then analyzed descriptively to discuss The Fate of Glyphosate in Soil and Water containing: What is the glyphosate; Interaction beween glyphosate and soil: (1) The role of clay minerals on adsorption, (2) The role of organic material on adsorpsion, (3) The role of $\mathrm{pH}$ in adsorption, (4) Movement of glyphosate in soil and water; Degradation of glyphosate in soil and water; Conclussion.

\section{Result and Discussion}

\section{What Is the Glyphosate}

Glyphosate, the active ingredient of the herbicide Roundup and others is widely used to control a wide range of perennial and annual weeds. The chemical structure of this compound is presented in the Figure 1. Glyphosate has been reported to be rapidly inactivated when in contact with mineral and organic soils (Sprankle, et al, 1975b; Suwardji, 1998), and this rapid inactivation of glyphosate in soil has been suggested to be a result of rapid adsorption to soil constituents.

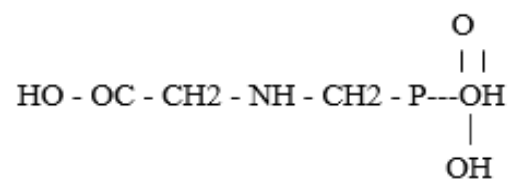

Figure 1. Chemical stucture of glyphosate

In a study of behaviour of glyphosate residue in soil using bioassay plants, Sprankle, et al. (1975a) found that the application of $56 \mathrm{~kg}^{\mathrm{ha}}{ }^{-1}$ glyphosate on clay loam and mucksoil did not significantly reduce the dry weight of wheat. The dose used in this experiment was 25 times of the proposed dosage normally used to control weeds. Similar results have been reported by other authors (Moshier, et al. 1976; Moshier \& Penner, 1978a; Klingman \& Murray, 1976; Egley \& William, 1978; Blowes, et al. 1985). As the roots of plant have been reported to be unable to absorb glyphosate (Hance, 1976), low activity of glyphosate in soil in these studies may be due to the combination of moderate adsorption and low acropetal uptake of this compound 
when applied to the root (Hance, 1976).

Due its strong adsorption of this compound when in contact with the soil constituents and rapid degradation in soil and water, it is generally believed that this compound is considered to be an environmentally safe.

\section{Interaction between Glyphosate and Soil}

How glyphosate binds to the soil particles is not well understood. Using bioassay plants, Sprankle et al. (1975a) found that a correlation existed between plant injury and the increase in the amount of inorganic phosphate applied to soils treated with glyphosate. This result suggested that glyphosate and inorganic phosphate may share the same adsorption site on soil, and that phosphate may have stronger affinity to compete with glyphosate for the adsorption sites. Consistent with this result, Hance (1976) showed that glyphosate adsorption has some correlation with the amount of unoccupied phosphate adsorption site in a wide range of soils, $\mathrm{r}^{2}=0.72, \mathrm{n}=9$. This suggested that glyphosate is likely to be adsorbed by soil constituents in a similar mechanism to that of orthophosphate but that orthophosphate is adsorbed preferentially.

Current work has been performed to further understand of the mechanism of sorption of glyphosate in soil. In an attempt to understand the mechanism binding of glyphosate to soil constituents, the interaction between glyphosate and humic acids and metal-humic complexes have been intensively investigated (Miano, et al., 1992; Piccolo, et al., 1992; Piccolo \& Celano, 1994; Piccolo, et al. 1994; Piccolo, et al. 1995a; Suwardji, 1998). Piccolo, et al., (1994) showed that adsorption of glyphosate in some European soils increased with an increase in the amount of amorphous iron (oxalate extractable). This finding confirmed the postulated ligand exchangemechanism as proposed by Sprankle, et al., (1975a) and Torstensson, (1985) for glyphosate, in which a hydroxyl of the iron hydration sphere is exchanged by the $\mathrm{P}-\mathrm{OH}$ group of the phosphonic moiety of the glyphosate. Moreover, the adsorption isotherm study of glyphosate on Fe-humic complex showed the S-type of the Giles (1960) classification. The S-type adsorption isotherm explains the relationship of the attraction between the glyphosate molecules in solution and those already adsorbed on the substrate and thereby producing an enhanced affinity at higher concentration (Piccolo, et al. 1992). This result suggests that there are two adsorption mechanisms operating simultaneously. At low glyphosate concentration, adsorption occurs through the exchange of an hydroxyl associated with the iron hydration sphere by a P-O- group of the phosphonic moiety of herbicide (Piccolo et al. 1992; Piccolo, et al. 1995b). This type of interaction is considered to be very strong binding and occurs during the phosphate fixation on iron hydrous oxides in soil (Parfitt et al. 1975). At high concentrations of herbicide, glyphosate to be adsorbed on already adsorbedmolecules by intermolecular hydrogen bonding that may occur between the electronegative atoms of the herbicide (Piccolo, et al., 1992; Piccolo, et al., 1995a). Further investigations of the interactions between glyphosate and pure humic acid demonstrated that glyphosate could establish multiple hydrogen bonding (Miano, et al., 1992). They showed that the interaction of glyphosate and humic acids (HA) is through the formation of multiple hydrogen bond as evidenced by infrared spectra with strong two absorption bands at 1170 and $1090 \mathrm{Cm}^{-1}$ for the stretching of the $\mathrm{P}=\mathrm{O}$ and $\mathrm{P}-$ $\mathrm{O}$ bonds of the phosphono groups of glyphosate. Picolo and Celano, (1994) suggested that the multiple hydrogen bonding may occur between phosphonic group of glyphosate and complementary oxygencontaining functional groups of the humic acid such as ketones and qui-ketones (Piccolo \& Celano, 1994). Results from fluorescence spectra of the HA-glyphosate sample confirmed the occurrence of an increasing desegregation of humic molecules, possibly ascribed to the formation multiple hydrogen bonds by glyphosate (Miano, et al., 1992).

\section{Role of Clay Minerals In Adsorption}

Results of many studies of the role of clay minerals on sorption of glyphosate are ambiguous in the literature. The type of clay mineral is considered to have some influence on adsorption of glyphosate. For example, Miles and Moye, (1988) reported that glyphosate was much more extensively adsorbed by kaolinite and bentonite than by montmorillonite. By contrast, Glass (1987) showed that more glyphosate was adsorbed by illite than by kaolinite or montmorillonite. Inconsistent results in the literature of the effect of type of clay minerals on the adsorption of glyphosate may partly be due to the different concentration ranges of solutions used for adsorption study. For example the concentration of glyphosate solution used for adsorption study by Glass (1987) is almost 100 times greater than that used by Miles and Moye, (1988).

Further studies showed that the composition of cations on cation exchange sites of soil solids has a strong influence on adsorption of glyphosate. Sprankle et al., (1975b) investigated the influence of cation composition on bentonite clay using a wheat bioassay. They saturated bentonite clay with particular cations and treated with glyphosate at either 0 or $4.8 \mathrm{~L} \mathrm{ha}^{-1}$ of Roundup (360a.i. g-1 ha-1). Poor wheat growth was observed on the bentonite clay saturated with $\mathrm{Na}^{+}$, $\mathrm{Ca}^{2+}, \mathrm{Mg}^{2+}$, suggesting lower adsorption of glyphosate in clays saturated with these cations. As glyphosate is 
unlikely to be absorbed through plant roots (Hance 1976), poor wheat growth in the clay saturatedwith $\mathrm{Na}^{+}, \mathrm{Ca}^{2+}, \mathrm{Mg}^{2+}$ may be due to inhibition of wheat roots by the soluble glyphosate and subsequent lower uptake of nutrients and water. In contrast, greater plant growth was observed under bentonite clay saturated with the $\mathrm{Zn}^{2+}$, suggesting greater adsorption of glyphosate. No differences in the fresh weight of the shoot of wheat plant was noted on clay saturated with $\mathrm{Mn}^{2+}$ and $\mathrm{Al}^{3+}$ and then treated with glyphosate (Sprankle et al. 1975b). Results from an adsorption studyusing ${ }^{14} \mathrm{C}$ glyphosate confirmed the bioassay study (Sprankle et al. 1975b). In this study, glyphosate adsorption on bentonite clays saturated with cations decreased as: $\mathrm{Al}^{3+}>\mathrm{Fe}^{3+}>\mathrm{Mg}^{2+}>\mathrm{Zn}^{2+}>\mathrm{Mg}^{2+}>\mathrm{Zn}^{2+}>\mathrm{Mn}^{2+}>$ $\mathrm{Ca}^{2+}$ (Sprankle et al. 1975b) The strong adsorption of glyphosate to $\mathrm{Al}^{3+}$ and $\mathrm{Fe}^{3+}$ further supported the concept that phosphate might be implicated in adsorption (Torstensson, 1985).

It is possible that bentonite saturated with $\mathrm{Fe}$ and $\mathrm{Al}$ exchanges sufficient amounts of the $\mathrm{Fe}$ and $\mathrm{Al}$ into the solution to enable these two metals to bind glyphosate by forming a chelate. A chelation of glyphosate has been postulated by McBride (1994). He pointed out that glyphosate is capable of forming a terdenate (three bonds) or tetradenate (four bonds) chelate with several of the coordination position on the surface metal ions being occupied by ligand group (Figure 2).

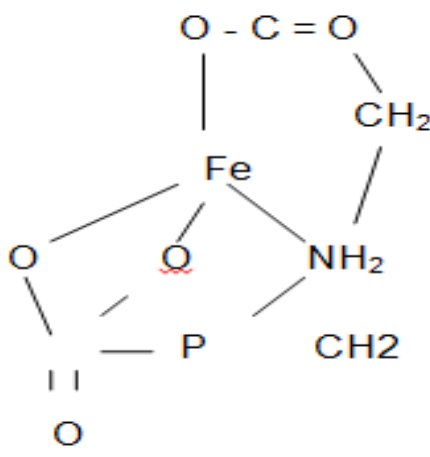

Figure 2.Chelate formation between lyphosate and iron (McBridge 1994)

Like clays, cations in association with the surface of organic matter have a strong influence on the extent of glyphosate adsorption. When glyphosate was applied in the organic mattersaturated with $\mathrm{Ca}^{2+}$ or $\mathrm{Na}^{+}$, a significant reduction of fresh weight of wheat plants was apparent (Sprankle, et al., 1975b) indicating of little adsorption of glyphosate. However, the organic matter saturated with $\mathrm{Mn}^{2+}, \mathrm{Fe}^{3+}$ or $\mathrm{Al}^{3+}$ did not significantly reduce the fresh weight of wheat, indicating greater adsorption of glyphosate. Moreover, Hensley, et al., (1978) reported that the increased percentage of soil organic matter and the addition of $\mathrm{Fe}^{3+}$ and $\mathrm{Al}^{3+}$ reduced the soil activity of glyphosate, but inactivation of glyphosate did not well correlate with the amount of soil organic matter and cation exchange capacity. This indicates that saturation of cations on the organic matter was much more important than both the amount of soil organic mater and the amount of cation exchange sites available. They suggested that adsorption of glyphosate onto organic matter might be enhanced by the formation of $\mathrm{Fe}^{3+}$ and $\mathrm{Al}^{3+}$ complexes with glyphosate. They also noted that there was no significant inactivation of glyphosate with the addition of $\mathrm{CaCl}_{2}, \mathrm{NaCl}$, and $\mathrm{KCl}$ butthe addition of $\mathrm{FeCl}_{2}, \mathrm{FeCl}_{3}$, and $\mathrm{AlCl}_{3}$ significantly reduced the activity of glyphosate. Further, a precipitation test indicated that a red-brown precipitate was formed when glyphosate and $\mathrm{FeCl}_{3}$ were allowed to stand in solution. They suggested that the adsorption of glyphosate may partly be due to the formation of metalglyphosate complexes, perhaps similar to those postulated by McBride (1994).

\section{The role of organic material on adsorption}

The adsorption of glyphosate on soil organic matter has been shown to be related to the degree of humification of organic matter. The application of glyphosate to a muck (organic) soil did not injure Barnyard grass (Echinochloa crugalli (L) Beauv) and Italian grass. Sprankle, et al., (1975b) demonstrated that glyphosate was rapidly inactivated in muck soil. However, when glyphosate was applied into sphagnum peat (non-decomposed plant materials), injury of Barnyardgrass (Echinochloa crugalli (L) Beauv) and Italian ryegrass (Lilium multiflorium Lam) was observed, indicating that non-decomposed organic matter did not render glyphosate unavailable. As previously mentioned the plant root system is unlikely to be able to absorb glyphosate, hence the injury of Barnyardgrass or Italian ryegrass could be due to substantial amount of glyphosate residue in soil solution which may inhibit the root system of the seedling plants in the early establishment. These results suggest that the fresh plant materials do not render glyphosate biologically unavailable.

\section{The role of $\mathrm{pH}$ in Adsorption}

The $\mathrm{pH}$ of soil systems influences the adsorption of glyphosate. Glyphosate is zwitterionic, therefore the charge structure of the molecule is dependent on the $\mathrm{pH}$ of the systems (Sprankle, et al., 1975b) as shown in the Figure 2. 12. Some studies showed that soil $\mathrm{pH}$ had little effect on adsorption of glyphosate (Sprankle, et al. 1975b; Hance, 1976). However, McConnell and Hossner (1985) showed a strong negative correlation between $\mathrm{pH}$ and adsorption of glyphosate by montmorillonite 
and nontronite minerals. At lower $\mathrm{pH}$, there was a greater attraction between glyphosate and these clay minerals. This may have been due to an increase in positive charge on the end of layer clays at low $\mathrm{pH}$. As the soil $\mathrm{pH}$ increases ( $>4.5$ ), glyphosate becomes an activated anion, resulting in the electrostatic repulsion between the negatively charged clay mineral and glyphosate (McConnell \& Hossner, 1985). Similar observations were observed for the adsorption of glyphosate on kaolinite, hematite and goethite (McConnell \& Hossner, 1985). In this study, the maximum adsorption of glyphosate by kaolinite was achieved at $\mathrm{pH} 4.5$, the adsorption decreases as $\mathrm{pH}$ increases or decreases to the value of 4.5. This was probably due to the zero point of net charge (ZPNC) of this clay mineral being 3.7. At $\mathrm{pH}$ below 3.7 the end surface of kaolinite was net positively charged while at above $\mathrm{pH} 3.7$ was neutral to negatively charged (McConnell \& Hossner, 1985).

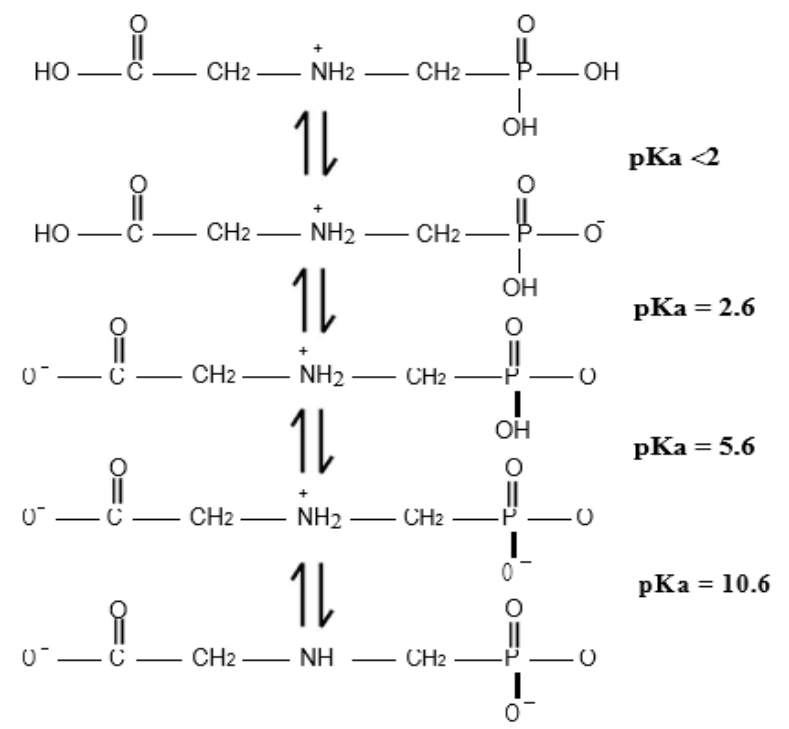

Figure 3. Proposed dissociation diagram and ionisation constant for glyphosate (Sprankle et al. 1975).

Both glyphosate and kaolinite lose their exchangeable proton as $\mathrm{pH}$ is raised. As a result both glyphosate and kaolinite become anionic, a decrease in the strength of adsorption occurs due to increasing repulsion between glyphosate and clay system. Similar patterns were observed for hematite and goethite. This evidence indicates that the $\mathrm{pH}$ of soil systems might influence the adsorption of glyphosate by two ways: (i) determine the charge structure of glyphosate, and (ii) influence the surface charge of $\mathrm{pH}$ dependent clays (McConnell \& Hossner, 1985).

More recently, Nicholls and Evans, (1991) showed that the maximum sorption of phosphate was similar in strength to that of glyphosate (Figure 4) and occurred at similar values of $\mathrm{pH}$. However when $\mathrm{pH}$ increased from $\mathrm{pH} 8$ to 10, adsorption of glyphosate did not decrease as much as that of phosphate. At $\mathrm{pH}$ values above 8.5 , the phosphate started to increase in such a way notobserved for glyphosate. While there may be some similarities in the binding mechanism between glyphosate and phosphate, the current evidence suggests that this mechanism is not the only binding mechanism operable and that other binding mechanisms of glyphosate are likely to exist.
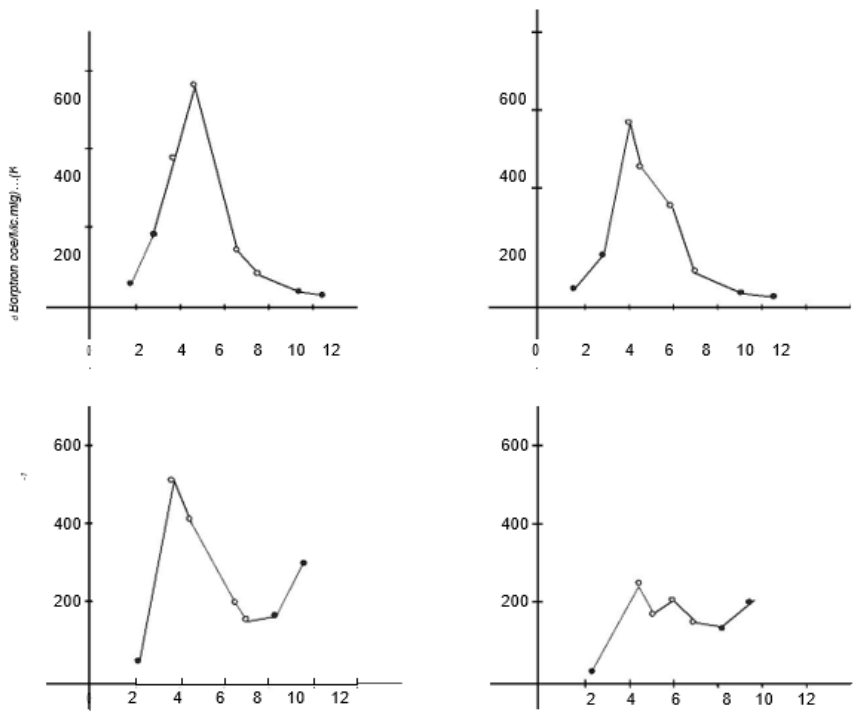

Figure 4. The influence of $\mathrm{pH}$ on the sorption of glyphosate (a) and inorganic phosphate (b). The R and W are silty clay and sandy loam soils respectively. Closed symbols are for soil where $\mathrm{pH}$ was adjusted by adding $\mathrm{HCl}$ or $\mathrm{Ca}(\mathrm{OH})$ solution (Nicholls \& Evans 1991).

\section{Movement of Glyphosate In Soil And Water}

Glyphosate is considered to be fairly immobile in soil. Using soil thin-layer plates, Sprankle, et al. (1975b) found that mobility of glyphosate is very slow with RF values from $0.04-0.2$. The mobility of glyphosate in the thin soil layer increased with increasing soil $\mathrm{pH}$ and level of phosphate in soil. The addition of phosphate is likely to compete with glyphosate for some adsorption sites, and leave more glyphosate in the soil solution. However runoff studies confirmed that glyphosate is relatively immobile and leaching is unlikely to occur in the field (Edwards, etal., 1980).

A recent study suggests that glyphosate may leach to deep layers in the soil profile. Piccolo and Cellano, (1994) investigated the binding interaction between glyphosate and water-soluble humic substances, and found that these substances were capable of rendering glyphosate becomes "biologically inactive" thatwater soluble. This humic substances finding may influence suggest the partitioning glyphosate at the soil-water interface and sufficient amount of glyphosate may bedistributed on the surface 
of soluble organic matter. And as the water-soluble humic substances are regarded as an important carrier of organic contaminants (Spark 1998), the adsorption of glyphosate on the surface of water-soluble humic substance may serve as a mechanism for enhanced mobility (Piccolo \& Cellano, 1994). The significance of dissolved humic acids inenhancingthe mobility of glyphosate in agriculture. However, as the amount of the dissolved humic substances in most soils is considered to be very low, it is likely to have only a minor role in affecting the movement of glyphosate in soil. However in agricultural practices in which sewage sludge is applied, leaching of glyphosate may be more prominent.

\section{Degradation of Glyphosate in Soil and Water}

Rapid biodegradation has been suggested to be the main route of glyphosate disappearance in soil and sediments (Bronstad \& Friestad, 1985; Sprankle, et al., 1975b; Torstensson, 1985; Rueppel, et al., 1977). Other processes such as chemical and photo decomposition have been shown to be oflittle importance regarding the decay of glyphosate in soil (Nomura \& Hilton, 1977; Rueppel, et al., 1977). However, Bronstad and Friestad, (1985) pointed out that photolysis may be an important process in influencing the disappearance of glyphosate in the aquatic system.

Results of many studies have shown that while soil microflora are responsible for decomposition of glyphosate in soil (Al Rajab et al, 2019; Sprankle, et al. 1975b; Torstensson \& Aamisepp, 1977; Rueppel, et al. 1977, \& Torstensson, 1985), the dominant process for decomposition is co-metabolism. Hence microorganisms do not use this compound as a carbon (C) or energy source (Sprankle, et al., 1975b; Torstensson \& Aamisepp, 1977; Nomura \& Hilton, 1977), but that degradation is likely to be due to soil enzymatic activity and no adaptation to growth on the herbicide or energy gain by organism has been observed (Torstensson \& Aamisepp, 1977; Torstensson, 1985). To date no soil microorganisms have been isolated from the field soil, which utilize glyphosate as carbon source (Carlisle \& Trevors, 1988). However, some Pseudomonas spp. isolated from activated sludge have been reported to be able to utilise glyphosate as a P source (Moorman, 1993).

Robertson and Alexander (1994) investigated the relationship between the occurrence of accelerated pesticide biodegradation and the susceptibility of the pesticide to growth-linked degradation and cometabolism. They found a slight increase in glyphosate metabolism in the second application but was not significantly different $(P<0.05)$. The initial amount of the population of glyphosate metabolising micro-organisms of $3.9 \times 10^{-4} \mathrm{~mL}^{-1}$ rose shortly after the first addition of glyphosate, but the second addition of glyphosate was not accompanied by a marked increase in cell number. As there is no significant increase in the rate of metabolism and the number of cells observed in the second addition, it is evident that microbes are unlikely to be able to utilise glyphosate as an energy source.

Many decomposition studies have used ${ }^{14} \mathrm{C}$ glyphosate to evaluate the rate of decomposition of glyphosate in soil (Torstensson, 1985). This method is attractive because measuring the evolution of ${ }^{14} \mathrm{CO}_{2}$ is simple. However, the major disadvantage of this method is that the primary substance (glyphosate) is not analysed for (Torstensson, 1985). The use of the ${ }^{14} \mathrm{CO}_{2}$-evolution rate as a measure of the rate of glyphosate degradation is only correct if ${ }^{14} \mathrm{CO}_{2}$ is released as ${ }^{14} \mathrm{C}$-glyphosate degrades (Torstensson 1985). Eberbach (1998) showed that the loss of triethylamine extractants glyphosate $\left(25^{\circ} \mathrm{C}\right)$ occurred at the same rate, as did the evolution of ${ }^{14} \mathrm{CO}_{2}$. Other work by Eberbach 1998 also indicated that AMPA was only a transitory immediate of glyphosate metabolism. These findings indicate that the rate of ${ }^{14} \mathrm{CO}_{2}$ evolution closely reflects the rate of ${ }^{14} \mathrm{C}$-glyphosate decomposition in soil. The degradation of glyphosate has been reported to be very rapid in the first few days slowing down with time to the steady state rate of decomposition (Eberbach, 1998; Nomura \& Hilton, 1977; Torstensson, 1985). Rapid decomposition of glyphosate in the first few days has been thought to be due to rapid metabolism of soluble (un-bound) glyphosate. While the slow degradation in the later stage was ascribed to the decomposition of glyphosate from the most slowly available (the bound fraction) (Eberbach, 1998; Nomura \& Hilton, 1978; Torstensson, 1985).

A number of factors affect the degradation of glyphosate in soil. The addition of phosphate enhanced the degradation of glyphosate in some, but not all soils (Sprankle, et al., 1975b; Hensley, et al., 1978). The reason for this is not clear but this may in part be due to differences in the extent ofun-occupied phosphate adsorption sites as, it has been found to correlate highly with the adsorptionof glyphosate (Hance, 1976). The addition of cations such as $\mathrm{Fe}$ and $\mathrm{Al}$ inhibited glyphosate degradation (Moshier \& Penner 1978b). This is particularly due to a change in the adsorption site, and hence the availability of glyphosate in soil. More recently, Picollo, et al. (1995a) found that the complexes Fe-humic substances were capable of adsorbing glyphosate in soil and may reduce its availability for decomposition. Soil $\mathrm{pH}$ has also been reported to have little effect on the degradation of glyphosate (Moshier \& Penner, 1978b).

The half-life of glyphosate in soil is quite variable, ranging from few days to several years 
(Eberbach 1998; Nomura \& Hilton 1977; Torstensson 1985). In a study using four Victorian soils, Eberbach (1998) showed that the half-life of glyphosate in the soluble phase was very short; in the order of one week. However the estimate half-life of glyphosate in the sorbed phase varied considerably; in the 4 soils investigated half-lives ranged from 7 months to 6 years. Eberbach (1998) suggested that this be attributed to the influence of sorption-desorption characteristic of soil on the availability of this compound for microbial cometabolism. A considerable difference in the rate of glyphosate decomposition between soils reported in the literature may be due to differences in the strength of adsorption that render glyphosate un-available for decomposition.

\section{Conclussion}

The behaviour of pesticide particularly glyphosate in soil and sediment have been discussed. The nature and properties of a pesticide strongly influence the way by which it can be adsorbed by soils and sediments. The role of soil organic matter, clay mineral, and amorphous minerals on the adsorption of pesticide depends primarily on the nature and properties of the soil itself and the properties of pesticide. Environmental factors have some influence on sorption and degradation of pesticide.

Adsorption limits the availability of pesticide for microbial degradation. The sorbed pesticide is not directly available to microorganisms in soil. Evidence suggests that not only a strongly sorbed compound such as paraquat but also weakly sorbed compounds such as flumetsulam and picloram can persist for long periods when they are sorbed by soil constituents. This suggests that the interaction between sorption and biodegradation should be considered in predicting the fate of pesticides in soils and sediments.

Glyphosate is rapidly inactivated in soil, is in part due to adsorption. However adsorption of glyphosate may not occur in some sandy soils with low adsorption capacity. Some soil properties have been identified that strongly influence adsorption of glyphosate, such clay minerals, composition of cations in exchangeable site of clay and organic matter, unoccupied phosphate adsorption site, degree of humification, and $\mathrm{pH}$. Even though there is a similarity in the mechanism of binding between glyphosate and phosphate to soil solids, current evidence suggests that this mechanism is not the only binding mechanism operable, and that other binding mechanisms of glyphosate are likely to exist. The influence of phosphate on adsorption and decomposition of glyphosate in soil is not fully understood. The addition of phosphate increased the rate of glyphosate degradation in some soils but did not have such an effect in all soils. As phosphate is the common fertilizer applied in agriculture practice and it is applied in high amount in horticulture system, it is important to gain understanding the competition effect of phosphate on the adsorption behaviour of glyphosate that may occur in soil. Understanding the basic mechanism of sorption and desorption is required to avoid situation which may trigger the release of bond residues of glyphosate in field situations. In addition, information is lacking in the literature on the influence of environmental factors particularly temperature, concentration and repeated applications on adsorption and decomposition of glyphosate in soil.

Degradation of glyphosate is mainly through biodegradation and the dominant process is cometabolism. Rapid initial degradation followed by slower rate of degradation in the further stage suggests that adsorption influences its availability for microbial degradation. Little information is available on the influence of adsorption characteristic of wide ranges of soils on the rate of glyphosate degradation. The use of non steady state compartmental analysis provides a good tool to evaluate the dependence of glyphosate degradation on sorption characteristic of soil (Suwardji, 2000), and this technique has shown its applicability to evaluate the simultaneous processes of sorptiondesorption and degradation of this compound to allow for a clear understanding of their interrelationship.

Repeated applications of glyphosate will become common practice in the near future with development of glyphosate tolerant crops. This may influence partitioning of glyphosate into the soluble and sorbed phases and sorption-desorption behaviour of this compound in soil. To date, little, if any information is available in the literature on the influence of repeated applications of glyphosate on sorption dynamic and decomposition of this compound in soil.

\section{References}

Al-Rajab, A. J., \& Hakami, O. M. (2014). Behavior Of The Non-Selective Herbicide Glyphosate In Agricultural Soil. American Journal of Environmental Sciences, 10(2 SE-Research Article). https://doi.org/10.3844/ajessp.2014.94.101

Arunakumara, K. K. I. U., Walpola, B., \& Yoon, M.-H. (2013). Metabolism and degradation of glyphosate in aquatic cyanobacteria: A review. African Journal of Microbiology Research, 7, 4084$4090 . \quad$ Retrieved from: https://www.semanticscholar.org/paper/...c4f 
Bailey, G.W. \& White, J.L. (1970). Factors influencing the adsorption, desorption and movement of pesticides in soil. Residue Rev. 32: 29-92. Retrieved from:

https://link.springer.com/chapter/10.1007/9781-4615-8464-3_4

Baird, D.D., Upchurch, R.B., Homesley, W.B. and Franz, J.E. (1971). Introduction of a new broadspectrum post-emergent herbicide class with utility for herbaceous perennial weed control. Proc. North Centr. Weed Contr. Conf. 26: 64-68. Retrieved from: https://ci.nii.ac.jp/naid/10020520454/

Blowes, W.M., Schmalzl, K.J., \& Jones, S. (1985). Effect of glyphosate on the establishment, growth and nodulation of 14 pasture legume cultivars. Australian Journal of Experimental Agriculture, 25, 347-350. https://doi.org/10.1071/EA9850347

Bollag, J.-M., \& Liu, S.-Y. (1990). Biological Transformation Processes of Pesticides. In Pesticides in the Soil Environment: Processes, Impacts and Modeling (pp. 169-211). https://doi.org/https://doi.org/10.2136/sssabo okser2.c6

Bronstat, J.O. and Friestad, H.O. (1985). Behaviour of glyphosate in the aquatic environment. In Grossbard and Atkinson (Eds.). The Herbicide Glyphosate. Butterworths, London. pp. 200-205. Retrieved from: https://agris.fao.org/agrissearch/search.do?recordID=US201302646897

Brusseau, M. L., Jessup, R. E., \& Rao, P. S. C. (1991). Nonequilibrium sorption of organic chemicals: elucidation of rate-limiting processes. Environmental Science \& Technology, 25(1), 134142. https:// doi.org/10.1021/es00013a015.

Burchill, S., Hayes, M.H.B. \& Greenland, D.J. (1981). Adsorption. In D.J. Greenland and M.H.B. Hayes (Eds.). The Chemistry of Soil Processes. A WilleyInterscience. New York. pp. 221-400.

Burns, R.G. (1975). Factors affecting pesticide loss from soil. Soil Biochem. 4: 102-141. Retrieved from: https:/ / espace.library.uq.edu.au/view/UQ:0150 $\underline{\mathrm{fcC}}$

Calvet, R. (1980). Adsorption-desorption phenomena. In. Hance (Ed.). Interactions between herbicides and the soil. Academic Press. New York. pp: 1-30.

Carlisle, S.M. \& Trevors, J.T. (1988). Glyphosate in the environment (Review Article). Water Air Soil Pollut. 39: 409-420.

Cork, D. J., \& Krueger, J. P. (1991). Microbial Transformations of Herbicides and Pesticides. In S. L. Neidleman \& A. I. B. T.-A. in A. M. Laskin (Eds.), Advances in Applied Microbiology. 36. 1-66. Academic

Press.
https://doi.org/https://doi.org/10.1016/S00652164(08)70450-7

Cox, L., Hermosín, M. C., \& Cornejo, J. (1993). Adsorption of methomyl by soils of Southern Spain and soil components. Chemosphere, 27(5), 837-849.

https://doi.org/https://doi.org/10.1016/00456535(93)90015-W.

Eberbach, P. (1998). Applying non-steady-state compartmental analysis to investigate the simultaneous degradation of soluble and sorbed glyphosate (N-(phosphonomethyl)glycine) in four soils. Pesticide Science, 52(3), 229-240. https://doi.org/10.1002/(SICI)10969063(199803)

ebiomo, A., Ogundero, V., \& Bankole, S. (2012). The Impact of Four Herbicides on Soil Minerals. Research Journal of Environmental and Earth Sciences, 4, 617-624.

Edwards, W. M., Triplett Jr., G. B., \& Kramer, R. M. (1980). A Watershed Study of Glyphosate Transport in Runoff. Journal of Environmental Quality, 9(4), 661-665. https://doi.org/ 10.2134/jeq1980.00472425000900040024x

Egley, G., \& Williams, R. (1978). Glyphosate and Paraquat Effects on Weed Seed Germination and Seedling Emergence. Weed Science, 26(3), 249-251. https://doi.org/10.1017/S004317450004981X

Gerstl, Z., \& Mingelgrin, U. (1984). Sorption of organic substances by soils and sediments. Journal of Environmental Science and Health, Part B, 19(3), 297-312.

https://doi.org/10.1080/03601238409372432

Giles, C. H., MacEwan, T. H., Nakhwa, S. N., \& Smith, D. (1960). 786. Studies in adsorption. Part XI. A system of classification of solution adsorption isotherms, and its use in diagnosis of adsorption mechanisms and in measurement of specific surface areas of solids. Journal of the Chemical Society (Resumed), 0, 3973-3993. https://doi.org/10.1039/JR9600003973

Glass, R. L. (1987). Adsorption of glyphosate by soils and clay minerals. Journal of Agricultural and Food Chemistry, 35(4), 497-500. https://doi.org/10.1021/if00076a013.

Hamaker, J.W. and Thompson, J.M. (1972). Adsorption. In. Goring and Hamaker (Eds). Organic chemicals in the soil environment. I. pp.49-143.

Hance, R.J. (1976). Adsorption of glyphosate by soils. Pest. Sci. 7: 363-366.

Hance, R.J. (1988). Adsorption and bioavailability, In Gover (Ed.). Environmental chemistry of herbicides. 1. R. Boca Raton, Florida: CRC Press. pp. 1-19.

Hassett, J.J. and Banwart, W.L. (1989). The Sorption of Nonpolar Organics by Soils and Sediments. In 
Reactions and Movement of Organic Chemicals in Soils (eds B.L. Sawhney and K. Brown). https://doi.org/10.2136/sssaspecpub22.c2

Hayes, M.H.B. and Mingelgrin, U. (1991). Sorption and chemical transformation processes of small organic chemical in soil. In Bolt et al. (Eds). Interactions at the soil colloidal-soil solution interface. NATO ASI Series E.: Applied Sciences. 190. 324-407.

Hensley, D., Beuerman, D., \& Carpenter, P. L. (2006). The inactivation of glyphosate by various soils and metal salts. Weed Research, 18, 287-291. https://doi.org/10.1111/j.1365-

3180.1978.tb01162.x

Hermosin, M. C., \& Cornejo, J. (1991). Soil adsorption of 2,4-D as affected by the clay mineralogy. Toxicological \& Environmental Chemistry, 31(1), 6977. https://doi.org/10.1080/02772249109357674.

Kanissery, R., Gairhe, B., Kadyampakeni, D., Batuman, O., \& Alferez, F. (2019). Glyphosate: Its Environmental Persistence and Impact on Crop Health and Nutrition. Plants (Basel, Switzerland), $8(11)$,

499. https:// doi.org/10.3390/plants8110499

Klingman, D.L. and Murray, J.J. (1976). Germination of seeds of turfgrass as affected by glyphosate and paraquat. Weed Sci. $24.21191-192$. https://doi.org/10.1017/S0043174500065735

Koskinen, W.C. \& Harper, S. (1990). The retention processes: Mechanisms. In: H.H. Cheng (ed.). Pesticide in the soil environment: Processes, Impact, and Modeling. Soil Sci. Soc. Am. Book Series No 2. Madison. $51-77$.

Kremer, R.J. \& N.E. Means (2019). Glyphosate and glyphosate-resistant crop interaction with rhizophere microorganisms. European Journal of Agronomy, $31 . \quad 153-161$. https://doi.org/10.1016/i.eja.2009.06.004

McBride, M. (1994). Environmental chemistry of soils. Oxford University Press. 406 p. New York.

McConnell, J. S., \& Hossner, L. R. (1985). pHDependent adsorption isotherms of glyphosate. Journal of Agricultural and Food Chemistry, 33(6), 1075-1078. https://doi.org/10.1021/jf00066a014.

Miano, T. M., Piccolo, A., Celano, G., \& Senesi, N. (1992). Infrared and fluorescence spectroscopy of glyphosate-humic acid complexes. Science of The Total Environment, 123-124, 83-92. https:// doi.org/https://doi.org/10.1016/00489697(92)90135-F.

Miles, C. J., \& Moye, H. A. (1988). Extraction of glyphosate herbicide from soil and clay minerals and determination of residues in soils. Journal of Agricultural and Food Chemistry, 36(3), 486-491. https://doi.org/10.1021/jf00081a020.
Moorman, T.B. (1993). Pesticide degradation by soil microorganisms: Environmental, ecological, and management effects. Taylor and Francis Group.

Moshier, L., \& Penner, D. (1978). Factors Influencing Microbial Degradation of 14C-Glyphosate to 14CO2 in Soil. Weed Science, 26(6), 686-691. https://doi.org/10.1017/S0043174500064833

Moshier, L.J. \& Penner, D. (1978a). Use of glyphosate in soil seedling alfalfa (Medicago sativa) establishment. Weed Sci. 26: 163-166. https://doi.org/10.1017/S0043174500049584

Nicholls, P.H. \& Evans, A.A. (1991). Sorption of ionisable organic compounds by field soils. Part 2. Cations, bases and zwitterions. Pest. Sci. 33: 331-345. Retrieved

from:

https://agris.fao.org/agrissearch/search.do?recordID $=$ GB9127004

Nomura, N.S. \& Hilton, H.W. (1977). The adsorption and degradation of glyphosate in five Hawaiian sugarcane soils. Weed Research, 17: 113-121. https://doi.org/10.1111/j.13653180.1977.tb00454.x.

Parfitt, R., Atkinson, R., \& Smart, R. (1975). The Mechanism of Phosphate Fixation by Iron Oxides1. Soil Science Society of America Journal SSSAJ, https://doi.org/10.2136/sssaj1975.036159950039 $00050017 x$.

Peruzzo, P. J., Porta, A. A., \& Ronco, A. E. (2008). Levels of glyphosate in surface waters, sediments and soils associated with direct sowing soybean cultivation in north pampasic region of Argentina. Environmental Pollution, 156(1), 61-66. https://doi.org/https://doi.org/10.1016/j.envp ol.2008.01.015.

Piccolo, A. \& Celano, G. (1994), Hydrogen-bonding interactions between the herbicide glyphosate and water-soluble humic substances. Environmental Toxicology and Chemistry, 13: 17371741. https://doi.org/10.1002/etc.5620131104.

Piccolo, A., Celano, G. and Pietramellara, G. (1992). Adsorption of the herbicide glyphosate on a metal-humic acid complex. The Sci. Total Environ. 123/124: 77-82.

Piccolo, A., Celano, G., \& Pietramellara, G. (1992). Adsorption of the herbicide glyphosate on a metal-humic acid complex. Science of The Total Environment, 123-124, 77-82. https://doi.org/https://doi.org/10.1016/00489697(92)90134-E.

Piccolo, A., Celano, G., Arienzo, M., \& Mirabella, A. (1994). Adsorption and desorption of glyphosate in some European soils. Journal of Environmental Science and Health, Part B, 29(6), 1105-1115. https://doi.org/10.1080/03601239409372918. 
Piccolo, A., Gatta, A. \& Campanella, L. (1995b). Interactions of glyphosate herbicide with acid and its iron-complex. Anall. di chimia. 85:35-40.

Piccolo, A., Gatta, L. \& Campanella, L. (1995a). Interaction of glyphosate with a humic acid and its iron complex. Anali di Chimica 85: 31-40.

Piccolo, A., Gatta, L., \& Campanella, L. (1995). Interactions Of Glyphosate Herbicide With A Humic Acid And Its Iron Complex. Annali Di Chimica, 85(1-2), 1-2.

Rampazzo, G. (2009). Behavior of organic pollutants in the soil environment. Special focus on glyphosate and AMPA. EQA: International Journal of Environmental Quality, 2. https://doi.org/10.6092/issn.2281-4485/3821

Rao, P.S.C. \& Hornsby, A.G. (2001). Behaviour of Pesticides in Soil and Water. Fact Sheet SL40, a series of the Soil and Water Science Department, Florida Cooperative Extension Services, Institute of Food and Agricultural Sciences, University of Florida. Retrieved from: https://agris.fao.org/agrissearch/search.do?recordID $=$ US9119910

Robertson, B. K., \& Alexander, M. (1994). Growthlinked and cometabolic biodegradation: Possible reason for occurrence or absence of accelerated pesticide biodegradation. Pesticide Science, 41(4), 311-318. $\underline{10.1002 / p s .2780410405}$

https://doi.org/

Rolando, C. A., Baillie, B. R., Thompson, D. G., \& Little, K. M. (2017). The Risks Associated with Glyphosate-Based Herbicide Use in Planted Forests. In Forests (Vol. 8, Issue 6). https://doi.org/10.3390/f8060208

Rueppel, M. L., Brightwell, B. B., Schaefer, J., \& Marvel, J.T. (1977). Metabolism and degradation of glyphosate in soil and water. Journal of Agricultural and Food Chemistry, 25(3), 517-528. https://doi.org/10.1021/if60211a018.

Sadegh-Zadeh, F., Abd Wahid, S., \& Jalili, B. (2017). Sorption, degradation and leaching of pesticides in soils amended with organic matter: A review. Advances in Environmental Technology, 3(2), 119132.

https://doi.org/10.22104/aet.2017.1740.1100

Salazar, N.M., Gramont, M.I.S., Floriano, F.G.Z., Olibarria, G.R., Hengel, M., \& Madrid, M.L.A. (2016). Dessipation of glyphosate from grapevine soils in Sanora Mexico. Tera Latinoamericana. 34: 385-391. Retrieved from: http:/ / www.scielo.org.mx/scielo.php?script=sci arttext\&pid=S0187-57792016000400385

Sarkar, B., Mukhopadhyay, R., Mandal, A., Mandal, S., Vithanage, M., \& Biswas, J. K. (2020). Chapter 8 Sorption and desorption of agro-pesticides in soils (M.
N. V. B. T.-A. D. Prasad Treatment and Remediation (ed.); pp. 189-205). ButterworthHeinemann.

https://doi.org/https://doi.org/10.1016/B9780-08-103017-2.00008-8

Scheunert, I (1992). Physical and physico-chemical processes governing the residue behaviour of pesticide in terrestrial ecosystems. In 'Terrestrial Behaviour of Pesticide'. (Eds. Scheunert, I. and Parlar, H.) pp. 1-22. Springer-Verlag, Berlin

Simonsen, L., Fomsgaard, I. S., Svensmark, B., \& Spliid, N. H. (2008). Fate and availability of glyphosate and AMPA in agricultural soil. Journal of environmental science and health. Part. B, Pesticides, food contaminants, and agricultural wastes, 43(5), 365-375.

https://doi.org/10.1080/03601230802062000.

Spark, K. (1998). The effect of transport path on the nature of soluble organic matter in soil leaches. Proc. National soil conference, Environmental benefits of soil management. Australian Soil Sci. Soc. Inc. April. 361-368.

Sprankle, P., Meggitt, W., \& Penner, D. (1975). Rapid Inactivation of Glyphosate in the Soil. Weed Science, 23(3), 224-228. https://doi.org/10.1017/S0043174500052917

Suwardji, Black, A.S., \& Eberbach, P. (1998).Sorption and Decomposition of Glyphosate in Soils Under four Temperature Regimes. Paper Presented at Australian New Zealand Soil Science Society Conference Brisbane Quendsland.

Sviridov, A. V., Shushkova, T. V., Ermakova, I. T., Ivanova, E. V., Epiktetov, D. O., \& Leont'evskii, A. A. (2015). Prikladnaia biokhimiia i mikrobiologiia, 51(2), 183-190. https://doi.org/10.7868/s0555109915020221.

Tarazona, J. V., Court-Marques, D., Tiramani, M., Reich, H., Pfeil, R., Istace, F., \& Crivellente, F. (2017). Glyphosate toxicity and carcinogenicity: a review of the scientific basis of the European Union assessment and its differences with IARC. Archives of toxicology, 91(8), 2723-2743. https://doi.org/10.1007/s00204-017-1962-5.

Torstensson, L. (1985). Behaviour of glyphosate in soils and its degradation. In. Grossbard and Atkinson (Eds.). The Herbicide Glyphosate. Butterworths, London. pp. 137-150.

Torstensson, N., \& Aamisepp, A. (2006). Detoxification of glyphosate in soil. Weed Research, 17, 209-212. https://doi.org/10.1111/j.13653180.1977.tb00468.x.

Villeneuve, Jean-Pierre; Lafrance, Pierre; Banton, Oliver; Frechette, Pierre; Robert, Claude (1988). A sensitivity analysis of adsorption and degradation parameters in the modeling of 
pesticide transport in soils. Journal of Contaminant

Hydrology, 3(1). 77-96.

https://doi.org/10.1016/0169-7722(88)90018-6

Wang, S., Seiwert, B., Kästner, M., Miltner, A., Schäffer,

A., Reemtsma, T., Yang, Q., \& Nowak, K. M. (2016). (Bio)degradation of glyphosate in watersediment microcosms - A stable isotope colabeling approach. Water research, 99, 91-100. https://doi.org/10.1016/j.watres.2016.04.041.

Weber, J.B. and Weed, S.B. (1974). Effects of soil on the biological activity of pesticides. In. Guenzi (Ed.) Pesticide in soil and Water. Soil Sci. Soc. Am. Inc. pp. 39-66.

Winkler, K. (1971). G. L. Atkins: Multicompartment Models for Biological Systems. 153 Seiten. Methuen Co. Ltd., London 1969. Geb. 35 s. Food/ Nahrung, 15(2), 225. https://doi.org/https://doi.org/10.1002/food.1 $\underline{9710150248}$

Zablotowicz, R. M., Accinelli, C., Krutz, L. J., \& Reddy, K. N. (2009). Soil depth and tillage effects on glyphosate degradation. Journal of agricultural and food chemistry, 57(11), 4867-4871. https://doi.org/10.1021/jf900272w.

Zhang, C., Hu, X., Luo, J., Wu, Z., Wang, L., Li, B., Wang, Y., \& Sun, G. (2015). Degradation dynamics of glyphosate in different types of citrus orchard soils in China. Molecules (Basel, Switzerland), 20(1), 1161-1175. https://doi.org/10.3390/molecules20011161.

Zimdahl, R., \& Gwynn, S. (1977). Soil Degradation of Three Dinitroanilines. Weed Science, 25(3), 247251.

https://doi.org/10.1017/S0043174500033397. 